\title{
METODE MAKE A MATCH DALAM PENINGKATAN HASIL BELAJAR IPA KELAS VII MATERI KLASIFIKASI SISTEM 5 KINGDOM
}

\author{
EVY ALDIYAH \\ SMP Negeri 202 Jakarta \\ evyaldy@gmail.com
}

\begin{abstract}
ABSTRAK
Pada pembelajaran materi Klasifikasi Sistem 5 Kingdom, banyak siswa menuturkan cukup merasa kesulitan memahami dan menghafalkan materinya, serta keaktifan siswa juga kurang maksimal. Dari permasalahan tersebut maka penulis mencoba mencari solusi dengan melakukan perubahan metode pembelajaran, diharapkan terjadi peningkatan terhadap keaktifan siswa selama proses pembelajaran materi tersebut dan hasil belajar siswapun meningkat. Metode pembelajaran kooperatif make a match dianggap sesuai dalam proses pembelajaran materi Klasifikasi Sistem 5 Kingdom. Tujuan penelitian ini untuk mencari solusi terhadap masalah pembelajaran siswa pada materi Klasfifikasi Sistem 5 Kingdom menggunakan pembelajaran kooperatif make a match serta meningkatkan motivasi belajar, keaktifan dan nilai hasil belajar siswa. Penelitian menggunakan metode Analisis Deskriptif, yang dilaksanakan pada 2 kelas paralel (7A dan 7C) dengan karakter siswa yang sama. Pada kelas sampel 7A dilakukan pembelajaran konvensional sementara pada kelas sampel 7C dilakukan kegiatan belajar dengan pendekatan make a match. Penelitian dilakukan selama 3 kali pertemuan sesuai dengan pemberian materi yang diagendakan. Pengumpulan data dilakukan pada saat kegiatan pembelajaran berlangsung dengan 3 tahap yaitu observasi, evaluasi belajar berupa pos test, dan wawancara. Hasil yang diperoleh adalah terjadi peningkatan signifikan terhadap persentase nilai hasil belajar dan keaktifan siswa pada kelas sampel yang diberikan pembelajaran kooperatif metode make a match. Sementara kelas sampel yang tidak diberikan hanya sedkit menampakkan peningkatan. Disimpulkan bahwa ada pengaruh terhadap keaktifan dan hasil belajar siswa yang diajar dengan metode make a match, peningkatan terjadi pada keaktifan dan hasil belajar siswa pada kelas yang diberikan pembelajaran dengan make a match dibandingkan siswa pada kelas yang diajar dengan metode konvensional.
\end{abstract}

Kata kunci : Belajar, Kooperatif, make a match, Aktifitas, Hasil Belajar

\section{PENDAHULUAN}

Tantangan utama bagi seorang guru adalah bagaimana upaya meningkatkan keaktifan belajar peserta didik. Berbagai upaya telah dilakukan, meskipun telah dilakukan secara maksimal tetapi belum sepenuhnya memberikan kepuasan. Dalam memecahkan masalah yang dihadapi tentu masih dibutuhkan pemikiran dan kerja keras. Lingkungan menjadi sangat berpengaruh bagi individu. Sebagaimana menurut Thompson (1957) dalam Asmiranti, Y. Laras (2016) tentang pendidikan, pengaruh lingkungan menghasilkan banyak perubahan yang bersifat permanen dalam kebiasaan, pola pikir, sikap, tingkah laku, karakter, watak dan kepribadian. Selanjutnya 
pengembangan watak dan kepribadian menurut Asmiranti, Y. Laras (2016) termaktub di dalam Undang-Undang Republik Indonesia Nomor 20 tahun 2003 pasal 3 dimana pendidikan nasional bertujuan mengembangkan kemampuan dan membentuk watak serta peradaban bangsa yang bermartabat dalam rangka mencerdaskan kehidupan bangsa, bertujuan untuk berkembangnya potensi peserta didik agar menjadi manusia yang beriman dan bertakwa kepada Tuhan Yang Maha Esa, berakhlak mulia, sehat, berilmu, cakap, kreatif, mandiri, dan menjadi warga negara yang demokratis serta bertanggung jawab.

Sejak lama pembelajaran yang biasa dilakukan di dunia pendidikan di Indonesia dirasakan kurang mampu merangsang keterlibatan siswa karena titik beratnya pada pendekatan konvensional. Sementara akhir dari pendidikan itu sendiri mengharapkan peserta didik menjadi lebih kreatif dan cakap dalam hidup juga memiliki watak, karakter dan pola pikir yang baik.

Guru adalah kunci keberhasilan proses belajar mengajar. Bagaimana seorang guru melakukan transfer ilmu melalui kemampuannya dalam memilih strategi pembelajaran dan metode yang disesuaikan dengan materi pembelajaran adalah kunci keberhasilan dalam prestasi belajar siswa, seperti yang dikemukakan oleh Bernadeta dan Siregar (2019). Namun tetap diharapkan agar siswa berpartisipasi aktif sehingga terjadi hubungan simbiosis menguntungkan timbal balik antara guru dan siswa.

Pada pembelajaran Kompetensi Dasar Klasifikasi Makhluk Hidup pada materi Klasifikasi Sistem 5 Kingdom, banyak peserta didik menuturkan cukup merasa kesulitan memahami dan menghafalkan materinya, sehingga terasa cukup membosankan dan keaktifan peserta didik juga kurang maksimal. Dari permasalahan tersebut maka penulis mencoba mencari solusi dengan melakukan perubahan metode pembelajaran untuk meningkatkan partisipasi aktif siswa selama kegiatan belajar pada materi tersebut sehingga hasil belajar pun meningkat. Banyak sekali metode pembelajaran yang ada, namun penulis merasa metode make a match lah yang sesuai dalam proses pembelajaran materi Klasifikasi Sistem 5 Kingdom pada Kompetensi Dasar Klasifikasi Makhluk Hidup.

Bekerja sama adalah karakter yang tampak pada pembelajaran kooperatif make a match ini, dapat digunakan pada semua mata pelajaran dan semua tingkatan usia anak didik, sebagaimana yang dikemukakan oleh Anita Lie (2008). Prinsip-prinsip pembelajaran kooperatif yang tampak pada metode make a match ini antara lain saling ketergantungan positif antara siswa dalam mencapai suatu tujuan, interaksi promotif yang saling mendukung dimana siswa mendorong siswa lainnya untuk belajar, keterampilan kolaburatif siswa dalam memecahkan konflik dan mengambil inisiatif bersama, serta terjadinya dinamika kelompok yang memunculkan kekuatan dalam membentuk kerjasama yang saling menguntungkan dalam mengatasi permasalahan, sebagaimana yang dipaparkan dalam buku Panduan Pembelajaran untuk SMP oleh Kemendikbud RI (2016).

Kegiatan siswa dalam metode make a match menurut Wahab (2007) dalam Asmiranti, Y. Laras (2016) adalah mencari pasangan kartu yang dipegang sebagai jawaban soal dengan batas waktu, terdapat reward bagi siswa yang dberhasil mencocokkan dan ada punishment bagi siswa yang tidak berhasil, sesuai dengan 
kesepakatan antara guru dan siswa. Juga melatih kecepatan berpikir dengan teliti, cermat dan tepat.

Zainal Aqib (2018) mengatakan bahwa pembelajaran metode make a match (mencari pasangan) dikembangkan oleh Lorn Curran pada tahun 1994. Langkah pelaksanaan metode pembelajaran make a match yang dikemukakan oleh Zainal Aqib (2013) yaitu penyiapan kartu oleh guru (kartu soal dan kartu jawaban), pembagian kartu kepada siswa untuk dipikirkan jawabannya/pasangan jawaban dari kartu yang dipegang, pencocokan kartu yang dipegang dengan dibatasi waktu (siswa mencari pasangan), verifikasi hasil pencocokan kartu, terakhir kesimpulan. Kegiatan dapat diulangi lagi dengan pengocokan kartu.

Dapat disimpulkan bahwa pembelajaran kooperatif make a match adalah metode pembelajaran kelompok dengan tujuan memahami konsep melalui permainan kartu berpasangan dengan pembatasan waktu dalam suasana belajar yang menyenangkan. Memungkinkan siswa menjadi lebih aktif dan kreatif dalam kegiatan belajar sehingga memudahkan dalam memahami dan penguasaan materi yang diberikan. Dan pendekatan pembelajaran make a match inilah yang penulis perkirakan merupakan solusi dalam pembelajaran IPA kelas VII Kompetensi Dasar 3.2. Klasifikasi Makhluk Hidup pada materi Klasifikasi Sistem 5 Kingdom. Diharapkan akan memberikan pengaruh terhadap motivasi dan pretasi belajar siswa kelas VII di SMP Negeri 202 Jakarta.

Tujuan penelitian : (1) Untuk mencari solusi terhadap masalah pembelajaran siswa pada materi Klasifikasi Sistem 5 Kingdom mengunakan pembelajaran kooperatif make a match. (2) Untuk meningkatkan motivasi belajar, keaktifan dan hasil belajar siswa.

\section{METODE PENELITIAN}

Penelitian ini menggunakan metode Analisis Deskriptif. Menurut Sugiyono (2013), metode Analisis Deskriptif adalah statistik yang digunakan untuk menganalisis data dengan cara mendeskripsikan atau menggambarkan data yang telah terkumpul sebagaimana adanya tanpa bermaksud membuat kesimpulan yang berlaku untuk umum atau generalisasi.

Pelaksanaan penelitian dilakukan pada 2 kelas paralel ( 7A dan 7C) dengan karakter peserta didik yang sama, dimana kelas sampel 7A tidak diberikan pembelajaran kooperatif make a match sementara kelas sampel 7C diberikan pembelajaran dengan pendekatan make a match. Penelitian dilakukan selama 3 kali pertemuan sesuai dengan pemberian materi yang diagendakan yaitu 14 Agustus 2019, 16 Agustus 2019 dan 21 Agustus 2019 , bertempat di SMP Negeri 202 Jakarta, Jalan Buluh Perindu IV/1 Duren Sawit Jakarta Timur.

Penelitian dilaksanakan pada saat kegiatan pembelajaran berlangsung, data dikumpulkan dengan 3 tahapan, yaitu : 1) Tahap Observasi dilakukan selama pembelajaran berlangsung. Guru mengamati keaktifan dan aktivitas siswa menggunakan pedoman observasi sebagai instrument penelitiannya. Data yang diperoleh bersifat kualitatif.2) Tahap Evaluasi : 1) Evaluasi keaktifan siswa dalam pembelajaran melalui observasi selama kegiatan pembelajaran berlangsung, 2) Evaluasi prestasi belajar setelah kegiatan pembelajaran berlangsung (pos test). Data 
yang diperoleh bersifat kuantitatif. Instrument penilaian pos test berupa 10 soal pilihan ganda yang digunakan untuk menilai pemahaman dan penguasaan siswa terhadap materi pembelajaran yang diberikan serta memperoleh data peningkatan hasil belajar siswa pada materi atau pokok bahasan yang diajarkan. Pembuatan soal memperhatikan tingkat kesukaran soal dan dibuat sendiri oleh guru sesuai silabus. 3) Tahap Wawancara dilakukan di akhir setelah materi pembelajaran selesai yaitu pada pertemuan ke 3, menggunakan instrument berupa daftar pertanyaan terhadap beberapa peserta didik yang dipilih. Bertujuan untuk mengumpulkan data mengenai kesan siswa selama mengikuti pembelajaran. Data yang diperoleh bersifat kualitatif.

Indikator capaian keberhasilan untuk tingkat keaktifan siswa adalah 75\% (jumlah kriteria baik dan cukup baik) dari observasi pada saat pembelajaran. Sedangkan untuk nilai hasil belajar indikator capaian keberhasilannya dilihat dari nilai pos test siswa yang mencapai atau melampaui KKM (73).

Persentase didapat dari penghitungan data yang diperoleh, dengan cara : Persentase $=$ Rata-rata frekuensi nilai/Jumlah siswa yang terlibat $x 100 \%$. Selanjutnya hasil analisis data disajikan secara deskriptif

\section{HASIL DAN PEMBAHASAN}

Hasil prestasi belajar siswa dilihat dari hasil pos test selama 3 kali pertemuan dapat diketahui melalui tabel dan diagram berikut :

Tabel 1. Frekuensi Nilai Hasil Belajar Kelas 7A(Jumlah siswa 36 orang)

\begin{tabular}{ccccc}
\hline Pertemuan & \multicolumn{4}{c}{ Frekuensi Nilai } \\
\cline { 2 - 5 } & $\mathbf{6 3}$ & $\mathbf{7 3 - 8 0}$ & $\mathbf{8 1 ~ - 9 0}$ & $\mathbf{9 1} \mathbf{- 1 0 0}$ \\
\hline $\begin{array}{c}\text { Ke 1 } \\
\text { (14 Agust 2019) }\end{array}$ & 18 & 16 & 2 & 0 \\
\hline $\begin{array}{c}\text { Ke 2 } \\
\text { (16 Agust 2019 }\end{array}$ & 17 & 16 & 2 & 1 \\
\hline $\begin{array}{c}\text { Ke 3 } \\
\text { (21 Agust 2019 }\end{array}$ & 17 & 17 & 2 & 0 \\
\hline Rata-rata & 17,3 & 16,3 & 2 & 0,3 \\
\hline Persentase & 48,1 & 45,3 & 5,6 & 0,8 \\
\hline Total & 48,1 & & 51,7 & \\
\hline
\end{tabular}

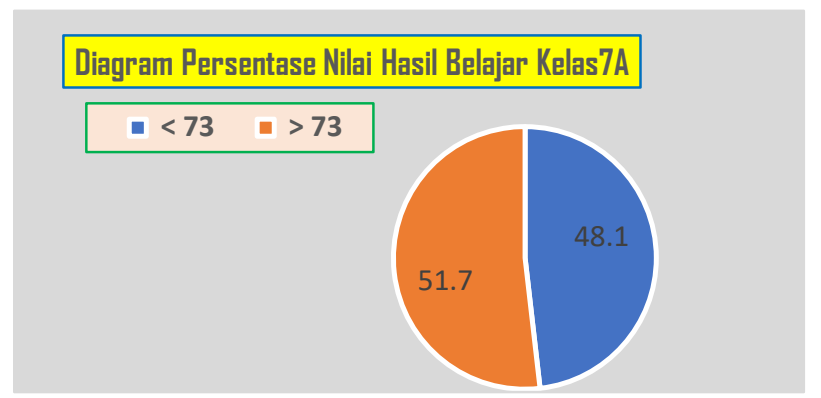

Gambar 1. Diagram Persentase Nilai Hasil Belajar Kelas 7A 
Tabel 2. Frekuensi Nilai Hasil Belajar Kelas 7C (Jumlah siswa 36 orang)

\begin{tabular}{ccccc}
\hline Pertemuan ke & \multicolumn{4}{c}{ Frekuensi Nilai } \\
\cline { 2 - 5 } & $<\mathbf{7 3}$ & $\mathbf{7 3 - 8 0}$ & $\mathbf{8 1 - 9 0}$ & $\mathbf{9 1} \mathbf{- 1 0 0}$ \\
\hline $\begin{array}{c}\text { Ke 1 } \\
\text { (14 Agust 2019) }\end{array}$ & 17 & 10 & 4 & 5 \\
\hline $\begin{array}{c}\text { Ke 2 } \\
\text { (16 Agust 2019 }\end{array}$ & 10 & 7 & 8 & 5 \\
\hline $\begin{array}{c}\text { Ke 3 } \\
\text { (21 Agust 2019 }\end{array}$ & 3 & 11 & 12 & 10 \\
\hline Rata-rata & 10 & 9,3 & 8 & 6,7 \\
\hline Persentase & 27,8 & 25,8 & 22,2 & 18,6 \\
\hline Total & 27,8 & & 66,6 & \\
\hline
\end{tabular}

Gambar 2. Diagram Persentase Nilai Hasil Belajar Kelas 7C

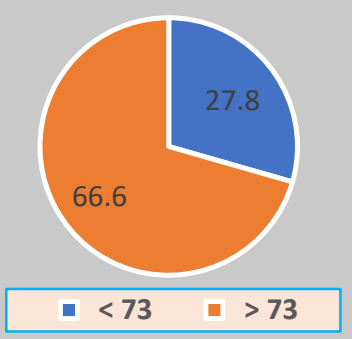

Diagram Persentase Nilai Hasil Belajar Kelas 7C

Kelas sampel 7A tidak menunjukkan peningkatan yang signifikan dan belum mencapai tingkat optimal. Frekuensi nilai kurang dari 73 tampak menurun dari pertemuan 1 ke pertemuan 2, namun tidak signifikan dengan persentase $48,1 \%$. Terjadi peningkatan frekuensi pada nilai $73-80$ dengan persentase $45,3 \%$, peningkatan terjadi pada pertemuan 2 ke pertemuan 3, namun tidak signifikan. Tidak ada peningkatan frekuensi pada nilai 81 - 90 pada pertemuan 1 hingga pertemuan 3 dengan persentase $5,6 \%$. Dan pada nilai 91 - 100 pada pertemuan 1 hingga pertemuan 3 terjadi kurva gelombang naik dan turun dengan nilai yan tidak signifikan dengan persentase $0,8 \%$.

Sedangkan pada kelas sampel 7C tampak prestasi belajar siswa terjadi peningkatan yang signifikan setelah dilakukan pembelajaran metode make a match. Frekuensi nilai kurang dari 73 tampak menurun dari pertemuan 1 hingga pertemuan 3 dengan persentase $27,8 \%$. Untuk frekuensi nilai 73 - 80 pada pertemuan 1 hingga pertemuan 3 terjadi kurva gelombang turun dan naik dengan nilai yang cukup signifikan dengan persentase $25,8 \%$. Terjadi peningkatan frekuensi pada nilai $81-90$ pada pertemuan 1 hingga pertemuan 3 dengan persentase 22,2\%. Dan terjadi peningkatan frekuensi pada nilai 91 - 100 dengan persentase 18,6 , peningkatan terutama pada pertemuan 2 ke pertemuan 3 .

Keaktifan siswa dalam proses pembelajaran dapat diketahui melalui tabel dan diagram berikut : 
Tabel 3. Frekuensi Keaktifan Belajar Kelas 7A (Jumlah siswa 36 orang)

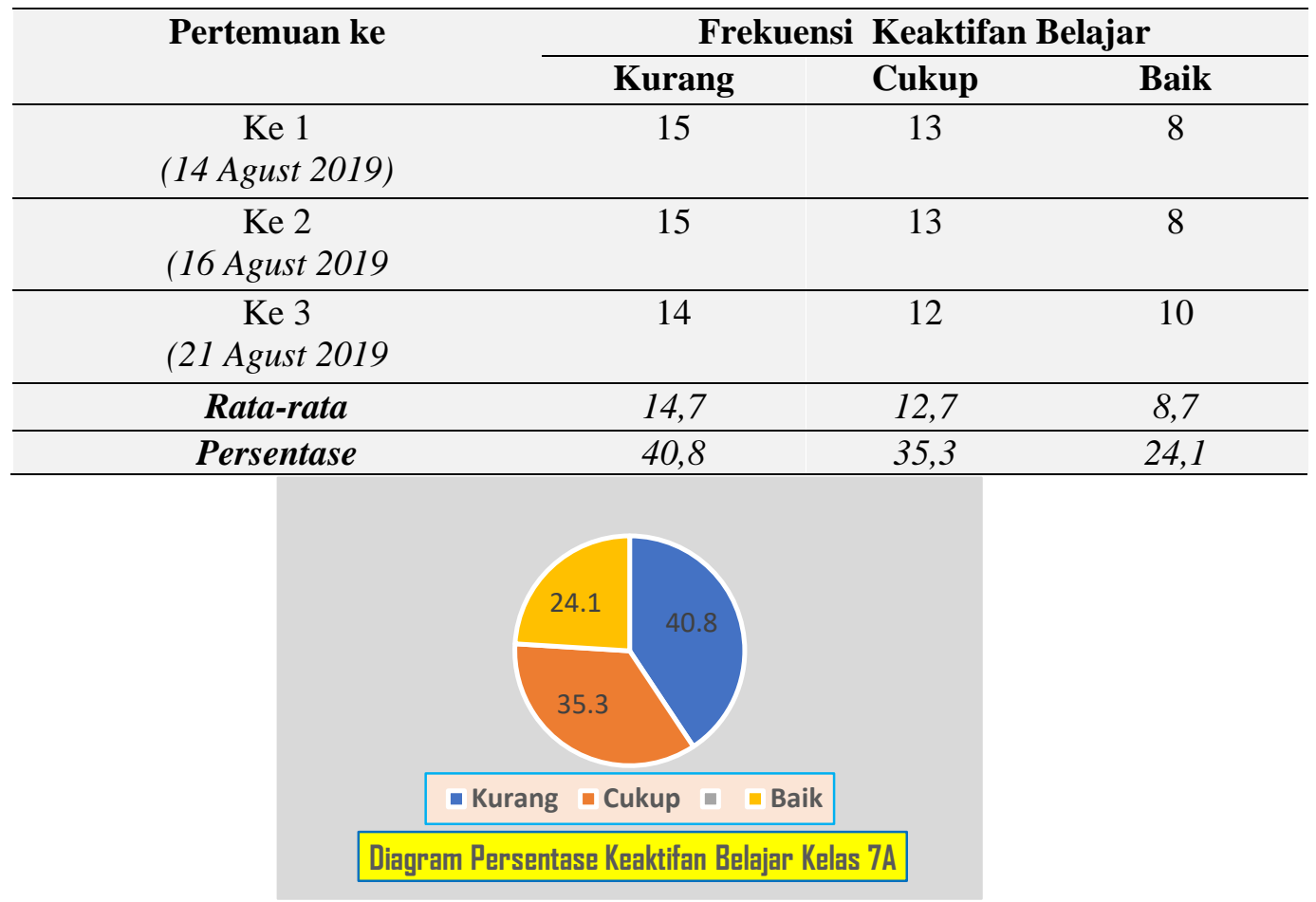

Gambar 3. Diagram Persentase Keaktifan Belajar Kelas 7A

Tabel 4. Frekuensi Keaktifan Belajar Kelas 7C (Jumlah siswa 36 orang)

Pertemuan ke

Ke 1

(14 Agust 2019)

Ke 2

(16 Agust 2019

Ke 3

(21 Agust 2019
Frekuensi Keaktifan Belajar

\begin{tabular}{ccc}
\hline Kurang & Cukup & Baik \\
\hline 8 & 10 & 17 \\
\hline 4 & 9 & 23 \\
\hline 2 & 6 & 28 \\
\hline 4,7 & 8,3 & 22,7 \\
\hline 13,1 & 23,1 & 63,1 \\
\hline
\end{tabular}

Persentase

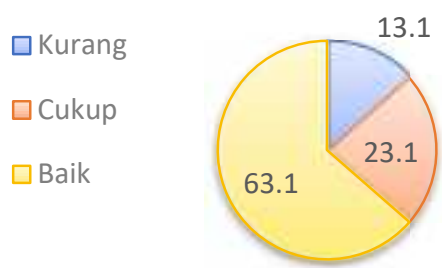

Diagram Persentase Keaktifan Belajar Kelas 7C

Gambar 4. Diagram Persentase Keaktifan Belajar Kelas 7C 
Kelas sampel 7A menunjukkan sedikit peningkatan pada keaktifan peserta didik dari petemuan 2 ke pertemuan 3 . Penurunan aktifitas peserta didik yang dinilai kurang aktif dan cukup aktif terkesan datar pada pertemuan ke 2 ke pertemuan 3 .

Sedangkan pada kelas sampel 7C memperlihatkan peningkatan keaktifan siswa yang sangat signifikan selama dan setelah pembelajaran. Pada petemuan 1 hingga pertemuan 3, jumlah siswa yang kurang aktif mengalami penurunan cukup signifikan. Begitu juga dengan jumlah siswa yang cukup aktif. Sementara siswa yang dinilai baik dalam keaktifan dan partisipasinya terjadi peningkatan yang sangat signifikan.

Jika dibandingkan persentase nilai hasil belajar dan persentase nilai keaktifan siswa dari tabel dan diagram tersebut maka dapat dilihat bahwa nilai hasil belajar dan keaktifan siswa pada kelas sampel yang diberikan pembelajaran metode kooperatif make a match mengalami peningkatan yang signifikan. Sementara kelas sampel yang tidak diberikan pembelajaran metode kooperatif make a match hanya sedkit menampakkan peningkatan. Artinya ada pengaruh pembelajaran yang diberikan terhadap keaktifan dan hasil belajar siswa. Sehingga metode make a match pada pembelajaran ini diharapkan dapat menjadi pendukung perkembangan keaktifan siswa selanjutnya.

\section{KESIMPULAN DAN SARAN}

Kesimpulan : (1) Pembelajaran kooperatif make a match memberikan pengaruh bagi keaktifan dan hasil belajar siswa, dimana siswa pada kelas yang diberikan pembelajaran metode make a match terjadi peningkatan dari segi keaktifan dan nilai hasil belajarnya. (2) Penerapan model pembelajaran kooperatif teknis make a match meningkatkan keaktifan dan nilai hasil belajar dalam pembelajaran Ilmu Pengetahuan Alam kelas VII Kompetesi Dasar 3.2. Klasifikasi Makhluk Hidup pada materi Klasifikasi Sistem 5 Kingdom. (3) Penerapan metode pembelajaran make a match meningkatkan motivasi siswa dalam bekerjasama, mengemukakan ide, menghargai pendapat teman, menghormati siswa lain yang lemah, dan mengembangkan kemampuan berfikir kreatif.

Saran : (1).Pemberikan penjelasan tentang langkah-langkah pembelajaran sangat diutamakan sebelum melaksanakan pembelajaran agar siswa siap dalam proses pembelajarannya serta memudahkan dalam mengendalikan situasi dan kondisi kelas secara optimal sesuai dengan waktu yang telah ditetapkan. (2).Harus diperhitungkan juga tingkat kesukaran soal pos test, disesuaikan dengan kondisi dan karakter siswa agar mendapatkan hasil yang diinginkan. (3).Diharapkan ada penelitian lanjutan dengan mengembangkan strategi atau metode pembelajaran lain yang sesuai materi pembelajaran

\section{DAFTAR PUSTAKA}

Asmiranti, Y. Laras (2016). Penggunaan Metode Make a Match Untuk Meningkatkan Hasil Belajar Siswa Pada Pembelajaran IPA Materi Ciri-Ciri Khusus Makhluk Hidup Kelas VI, Skripsi FKIP UNPAS. http://repository.unpas.ac.id/id/eprint/5520 diakses 12 Jul 2016 03:29 
Aqib, Zainal. (2013). Model-Model, Media, dan Strategi Pembelajaran Kontekstual. Bandung: Yrama Widya.

Bernadeta, J dan Siregar, T (2019). Metode Pembelajaran Role Playing dalam Meningkatkan Keaktifan dan Hasil Nilai Belajar IPA pada Materi Pertumbuhan Makhluk Hidup. e-Jurnal Ilmu Pendidikan Indonesia. Vol 7 no 2 hal 57-63 Juni 2019. http://ejurnal.uncen.ac.id/index.php/JIPI

Kemendikbud RI (2016). Metode-Metode Pembelajaran - Pemaduan Beberapa

Metode Pembelajaran (Panduan Pembelajaran Untuk SMP). Jakarta :

Kemendikbud RI.

Lie, Anita. (2010). Cooperative Learning : Mempraktikkan Cooperative Learning di Ruang Kelas. Jakarta: Gramedia.

Sugiyono (2013). Mertode Penelitian Kuantitatif dan Kualitatif. Bandung : Alfabeta. Sugiyanto (2009), Model-ModelPembelajaran Inovatif. Surakarta : Modul PLPG. 